\title{
EXTENDING THE FAMILY 500+ PROGRAMME - A CRITICAL ANALYSIS
}

\author{
ROZSZERZENIE PROGRAMU „RODZINA $500+$ + - KRYTYCZNA ANALIZA \\ https://doi.org/10.34739/zn.2021.55.01
}

\author{
Michał Krawczyk \\ Poland, Siedlce University of Natural Sciences and Humanities, Faculty of Social Sciences \\ michal.krawczyk@uph.edu.pl, ORCID: 0000-0003-3923-3576
}

\begin{abstract}
Starting from April 2016, the Polish government introduced a new type of social benefit - the childrearing benefit. Initially, it was granted to the second and subsequent children, and in the poorest families, to the first one. The Act of 26 April 2019 amending the Act on State Assistance in Upbringing Children as well as certain other acts extended, from 1 July 2019, the validity of the "Family $500+$ " programme to every child under 18 years of age, regardless of the family income criterion. The study analyses the underlying assumption and aim of the reform, and also attempts to answer the question: to what extent has broadening of the Family 500+ programme brought the expected results?
\end{abstract}

Keywords: pro-family policy, 500+ Programme, demography

\begin{abstract}
Abstrakt: Począwszy od kwietnia 2016 r. ustawodawca wprowadził nowy rodzaj świadczenia społecznego świadczenie wychowawcze. Początkowo przysługiwało ono na drugie i kolejne dziecko, a w rodzinach najuboższych także na pierwsze. Ustawą z dnia 26 kwietnia 2019 r. o zmianie ustawy o pomocy państwa w wychowywaniu dzieci oraz niektórych innych ustaw rozszerzono, począwszy od 1 lipca 2019 r., obowiązywanie programu „Rodzina 500 +" na każde dziecko do 18. roku życia, bez względu na kryterium dochodowe rodziny. W opracowaniu poddano analizie założenie i cel reformy oraz postarano się odpowiedzieć na pytanie, na ile rozszerzenie programu Rodzina 500+ przyniosło spodziewane efekty.
\end{abstract}

Słowa kluczowe: polityka prorodzinna, Program 500+, demografia

\section{Introduction}

The Act of 26 April 2019 amending the Act on State Child Support, as well as certain other acts extended, from 1 July 2019, the validity of the Family $500+$ programme to every child under 18 years of age, regardless of the family income criterion. It was rightly pointed out that the current version of the programme did not consider, for example, relatively poor one-child families, but covered affluent families with many children (Gromada, 2018, pp. 233-234). The main aim of the changes was to increase the fertility rate of Polish families and to improve their quality of life. The specific objectives are to provide all children with the means to develop their interests and increase their educational and developmental opportunities, to ensure continuity of services, and to simplify official procedures related to services.

\section{Sources and methodology of research}

The Article uses the Act of 26 April 2019 to amending the Act on State Child Support and certain other acts, the explanations for the draft of the above-mentioned Act, statistics, and analyses of parliamentary experts. The study also reviews scientific publications concerning the Family 500+ programme.

\section{Discussion and results}

The date April 1, 2021 will mark 5 years since the Government of Law and Justice introduced the Family $500+$ programme. The introduction of the programme in April 2016 was undoubtedly one of the more significant media events of the year (Krawczyk, 2012, p. 61). The 500+ benefit became the first regular transfer of public funds paid to the children (Świecka, 2017, p. 6). Child Benefit undoubtedly contributed positively to an increase in incomes and an increase in household 
consumption expenditure. Families receiving the $500+$ benefit assessed their overall situation as markedly improved (Hanusik, ŁangowskaSzczęśniak, pp. 134-135). For many families, Child Benefit enabled all household members to go on holiday for the first time and to meet family financial commitments (Gasz, 2018, p. 96). It is also worth noting that the funds from the Family 500+ programme constituted the second source of family income after income from work (Michalak, Warzocha, Liminowicz, 2018, p. 121). Families receiving Child Benefit spent money mainly on food and clothing $(42,6 \%)$. A large part of the respondents spent the granted money on nursery or school fees $(32,2 \%)$ and on children's education $(32 \%)$ and $11,8 \%$ of families spent the money on hobbies and entertainment for children (Węgrzyn, 2016, p. 274). On the other hand, however, voices have been raised that the Family 500+ programme is beginning to be treated as an objective in itself, and not as a means to achieve the desired objectives (Radzik, 2018, p. 70). As a financial transfer from the childless to those having children, from the elderly to the younger and middle-aged, from the richer to the poorer and from towns to countryside (Gajewicz, 2018, p. 86). The redistributive nature of the programme has also led to a posing of the question as to whether in the social, cultural and economic reality, the programme will preserve the clientelistic relations between the ruling class and a large swathe of society (Graniszewski, 2018, p. 67).

However, regardless of the above doubts, more than three fifths (62\%) of Poles assessed the current state policy towards the family at least as good. Slightly more than one fourth $(27 \%)$ of people considered it to be sufficient and $7 \%$ considered it to be insufficient. The state policy towards the family was highly rated by pensioners and farmers $(73 \%$ each), respondents engaged in religious practices at least once a week (71\%-73\%) and respondents with right-wing attitudes (78\%) (CPOR, Family 500 plus programme after three years of operation, Studies report, no. 52/2019, pp. 1-2).

In February 2019, at the party election convention in Warsaw, Jarosław Kaczyński announced new solutions. In the so-called Kaczyński's Five or the New Law and Justice Five, we could find payments from the Family 500+ programme for each child, the "thirteenth pension payment" to the amount of the lowest monthly pension from the Social Insurance Institution, zero PIT for employees under 26 years of age, reduction of labour costs and restoration of local bus connections. According to the results of the CPOR survey of March 2019, the extension of the Family $500+$ programme, so that the child-rearing benefit would also be paid for the first child was considered to be the most important of the five solutions announced. One in three respondents identified these as the most necessary (31\%) (CPOR, Social reactions to PIS's Five Solutions, Study Report, no. $45 / 2019$, p. 2). $44 \%$ respondents definitely supported the placing of all children under the programme, $31 \%$ rather advocated it, $9 \%$ were rather against, $10 \%$ were definitely against (CPOR, Reactions..., p. 1). However, when asked "Which of these solutions will be used by your household or by you personally?", $29 \%$ of respondents indicated the child-rearing benefit from the Family 500+ programme for each child (CPOR, Reactions..., p. 3 ). According to the results of the CPOR survey, the child-rearing benefit for each child was appreciated mainly by persons bringing up children - parents and respondents having children in the household. Nearly half of the respondents declaring that they have children under 18 years of age in their care (49\%), and more than two fifths of those having children in the household $(42 \%)$, indicated that the extension of the Family $500+$ programme as the solution most needed of all five announced. Low "per capita" income was also a factor in the positive response to the extension of the Family 500+ programme. Forty-two percent of people who had a monthly income per capita of less than PLN 900 and forty percent with a monthly per capita income ranging from PLN 900 to PLN 1299 considered it to be the most needed solution (CPOR, Reactions..., p. 4).

The Act of 26 April 2019 amending the Act on State Child Support as well as certain other acts extended, from 1 July 2019, the validity of the Family 500+ programme to every child under 18 years of age, regardless of the family income criterion. It was rightly pointed out that the current version of the programme did not consider, for example, relatively poor one-child families, but covered affluent families with many children (Gromada, 2018, pp. 233-234). The proposed changes were intended to be an important element of a broader family policy, defined by the three priorities: demography, namely increasing the birth rate, reducing poverty, especially among children, investment in the family (improving the "quality" of human capital) (Impact assessment of the regulations contained in the government's bill amending the Act on State Child Support and certain other acts, Parliamentary Analysis Office, Chancellery of the Parliament, 23 April 2019, p. 4).

Therefore, in the Act of 11 February 2016 on State Child Support (Journal of Laws of 2018, Items 2134 and 2354 and of 2019, Items 60, 303, 577 and 730) the provisions relating to all solutions concerning the income criterion entitling to Child Benefit, which directly referred to income, were repealed (such as the income catalogue, the 
amount of the income criterion or the loss and gaining of income), but also a number of provisions that were indirectly linked to the income-based conditionality of the granting of child-rearing benefit, such as the terms concerning disability or the definition of a family (Explanation to the proposed law on amending the Law on State Child Support and certain other laws, document no. 3387, p. 4). Following the amendment, the obligation to decide on the granting of Child Benefit by means of an administrative decision has been abolished in favour of a simpler solution involving issuing information about the granting of the benefit. However, in order to ensure the right of appeal, the obligation to issue administrative decisions remains in cases of refusal, revocation, and change of the right to parental benefit and in cases of unduly received benefits (Justification..., document no. 3387 , p. 4). Among the other most important solutions contained in the amendment to the Act, the following can be mentioned: 1) granting an allowance in the amount of the Child Benefit also to children from socialisation-type care and educational institutions, intervention-type care and educational institutions, specialist and therapeutic type care and educational institutions, regional care and therapeutic institutions and pre-adoption intervention centres; 2) introduction of a 3-month period for filing an application for the child-rearing benefit for a new-born child (so far it has been 1 month), with the right to equalise the payment of this benefit from the date of the child's birth; 3) introduction of the principle that after the death of a parent to whom a child-rearing allowance has been granted, the allowance should be taken over by the other parent without the allowance having to be reconsidered; 4) changes to the benefit period and application deadlines, so that the handling of applications from different programmes does not accumulate over time and does not result in any additional administrative burden (Results assessment..., Parliamentary Analysis Office, Chancellery of the Parliament, 23 April 2019, p. 2).

The extension of the Family $500+$ programme to all children up to the age of 18 generated expenditure for the state in 2019 in the amount of PLN 9576 million, and in the first full year of operation, that is 2020 - PLN 19859 million. The vast majority of the amount was allocated to childrearing benefits (only $0,4 \%$ of this amount was transferred as an allowance for children staying in care and educational institutions). These regulations have increased state budget expenditure to the benefit of families to around $4 \%$ GDP. This represented an increase of $125 \%$ compared to 2015 (before the introduction of the Family $500+$ programme this indicator was $1,78 \%$ ) (Results assessment..., p. 7). It is worth noting, however, that the funds paid out have largely returned to the budget in the form of indirect taxes as a result of increased consumption in Polish families (Franielczyk, 2018, p. 74). It is also worth pointing out that the amendment to the act has reduced the share of the costs of servicing the benefit in the targeted subsidy from the state budget for municipalities - these costs are to constitute $0,85 \%$ of the subsidy $(1,5 \%$ before the amendment). In 2020, this was the amount of PLN 350 million (in 2018, expenditure for this purpose totalled PLN 328 million). This reduction is due to the simplification of procedures and lower labour intensity of handling applications (Effect assessment..., p. 8). However, it is pointed out that the very high cost of the programme for the public finance sector will, at the same time, have a minimal impact on the incomes of the poorest families with children; and at the same time as there are significant benefits for families with medium and high incomes. The results of economic analyses indicate that out of the richest $20 \%$ of Polish households, families with children will gain PLN 5,4 billion a year from this reform, that is $30 \%$ of the total cost of extending the $500+$ benefit, and those from among the poorest $20 \%$ will gain only PLN 0,8 billion, that is $4 \%$ of the total cost of this extension. Such a distributive effect of extending the 500+ benefit is significantly different from the distribution of benefits from the child-rearing benefit in the form before the programme had been extended: out of the overall amount of PLN 21,9 billion a year, as much as PLN 3,5 billion (16\%) is paid to families from the richest $20 \%$ of households, and only PLN 4,9 billion (22\%) to families belonging to the poorest $20 \%$ of households (Results assessment..., p. 8 after: Myck, 2019, p. 19)

As was rightly emphasised in the study by the Parliamentary Analysis Office, the inclusion of all only children to the programme as the potential to overcome the so far negative perception of certain aspects of the programme which has been reflected in the CSO research findings (Results assessment..., Parliamentary Analysis Office, Chancellery of the Parliament April 2019, p. 6). It was stated that until the programme was extended, the most critical of the state's policy towards families were those who had children but did not receive benefits until the programme was extended. At the same time, the same research has shown that the introduction of the programme in 2016 resulted in reluctant reactions, for example, unfavourable comments from people who do not benefit from the child-rearing benefit to those benefiting from the Family $500+$ programme (CPOR, Family 500 plus programme after three years of running, Research report, no. 52/2019, pp. 5 and 7). 
However, it is difficult to determine how the extension of the Family 500+ programme will translate into the economic activity of parents, and particularly mothers. In the CSO modular survey "Work and Family Commitments", the respondents were asked whether, in connection with receiving Child Benefit, they have taken any actions aimed at changing their situation on the labour market. It turned out that in the vast majority of cases the $500+$ benefit did not have a direct impact on the respondents' actions in the labour market. Of the 5 million, $\quad 933000$ people aged 18-64, who are members of households that are or have been receiving this benefit, 95,1\% (for example $5 \mathrm{mln} 641$ 000) have not taken any action to change their situation on the labour market as a result of receiving this benefit payment. There were slight differences between women and men in this respect - $98,0 \%$ of men did not take any action to change their situation on the labour market, while among women this percentage figure stood at $92,6 \%$. Taking action to change their current situation in the labour market, which resulted from receiving the benefit of the 500+ programme was declared by a total of 291 thousand people - there were definitely more women (238 thousand) than men (53 thousand) among them. Among those who have undertaken any actions, the most frequently indicated change, made under the influence of receiving the $500+$ benefit, was taking up a job (76 thousand people) and starting to look for a job (75 thousand people). Counteracting actions: that is a cessation of job seeking and a resignation from work, were declared by 34000 and 33000 people respectively (CSO, Work and family responsibilities in the second quarter of 2018 (on the basis of preliminary results of the BAEL modular survey), $\mathrm{p}$. 4 ). On the other hand, however, CPOR research shows that the effect of the programme, which - in any way - has been encountered by the smallest percentage of people, is for a woman to take up employment $(79 \%$ of respondents have not heard of such cases). By contrast, almost a half of them have encountered cases of a mother giving up her job, $34 \%$ of which know such women only from the media or from friends (CSO, Jobs and responsibilities..., p.5). Opinions have also been expressed that extending the Family 500+ programme to every child may paradoxically increase women's economic activity. The lack of an income threshold for the first child (on which the granting of the benefit also depends) may result in women not having to resign from work to receive such a benefit (Gazeta Wyborcza, 500+ per first child can increase women's economic activity, online edition of: 27 December 2019 [access: 31.12.2019]).
It remains unclear whether the Family $500+$ programme, including its extension to the first child, will contribute to an increase in the number of children being born. The decrease in the number of births, as in other Western European countries, is caused, among other things, by a postponing of the decision to start a family and have children (Kotowska, 214, p. 20). In April 2019; that is after three years of the functioning of the Family 500+ programme, CPOR asked the Poles whether in their opinion it had contributed to the growth of birth rate in Poland or it has no influence on it. Almost one in four respondents $(24 \%)$ claimed that the Family $500+$ programme has a significant pro-birth effect. Less than half of Poles $(47 \%)$ believed that Child Benefit benefit plays a minor role, and $23 \%$ believed that it does not affect the birth rate at all. The youngest respondents noted more often than others a significant impact of the programme in terms of an increase in the number of births ( $41 \%$ persons aged 18-24 years); and respondents with the lowest level of education, low-skilled workers, unemployed and interviewed persons with the lowest monthly income per capita (37\% respectively). The opinion that the child-rearing benefit in its current form has not affected the number of births in Poland, was more often shared by the inhabitants of towns with more than half a million residents $(32 \%)$, managers and specialists with higher educational qualifications $(37 \%)$, selfemployed $(42 \%)$, persons not taking part in religious practices $(41 \%)$ and identifying themselves with leftwing views (45\%) (CPOR, Programme..., pp. 3-5). It is worth noting at this point that, although in 2016 the number of live births was 382,000 and was 13,000 higher than in the previous year, and in 2017 about 402,000 children were born, that is another 20,000; in 2018 the number of births fell to 388,000 . (CSO, Demographic yearbook 2019, Warsaw 2019, p. 26).

\section{Conclusion}

To sum up the above deliberations, simplifying the procedures for granting Child Benefit should be viewed positively. Nevertheless, it is appropriate to agree with the authors of the Parliamentary Analysis Office, that, although the extension of the Family $500+$ programme was an important element of a broader family policy, including measures to increase the birth rate, reduce child poverty and invest in human capital, it is difficult, at this point in time, to assess unambiguously the effectiveness of the measures introduced, especially in the light of the first of these objectives. The extension of the Family $500+$ programme undoubtedly entails a significant burden on the state budget. However, this burden may be considered to be inadequate to 
the expected results. Resignation from the income criterion may result in the assignment of funds not to the poorest families, but to those with average and higher incomes (Assessment of results ... p. 1). Among the proposed changes, there is the development of a family policy programme - a strategic document which would contain a reliable diagnosis of current family policy in the context of the demographic change which is taking place and the child-bearing barriers and the resulting challenges for public policy, and the definition of medium- and long-term objectives for this policy. Modifications to the Family 500 + programme should result from this programme and be part of the overall tax and benefit system and other family policy measures (institutional and informal childcare, the organisation of education, holidays, flexible working time and its organisation) as well as to ensure that the health infrastructure is adapted to changes in procreative behaviour and to health of people in reproductive age (Magda, Brzeziński et. Al. 2019, pp. 15-16).

\section{References}

\section{Legal acts}

Ustawa z dnia 27 sierpnia 1997 r. o rehabilitacji zawodowej i społecznej oraz zatrudnianiu osób niepełnosprawnych, t.j. Dz.U. z 2019 r. poz. 1172, 1495, 1696, 1818. [The Act of 27 August 1997 on Vocational and Social Rehabilitation and Employment of Disabled People].

Ustawa z dnia 29 sierpnia 1997 r. - Ordynacja podatkowa, t.j. Dz.U. z 2019 r. poz. 900, 924, $1018,1495,1520,1553,1556,1649,1655$, $1667,1751,1818,1978,2020,2200$. [Act of August 29, 1997 - Tax Ordinance].

Ustawa z dnia 28 listopada 2003 r. o świadczeniach rodzinnych, t.j. Dz.U. z 2018 r. poz. 2220, 2354, z 2019 r. poz. 60. 303, 577, 730, 752, 924, 1257, 1394, 1818. [Act of November 28, 2003 on Family Benefits].

Ustawa z dnia 9 czerwca 2011 r. o wspieraniu rodziny i systemie pieczy zastępczej, t.j. Dz.U. z 2019 r. poz. 1111, 924, 1818. [The Act of 9 June 2011 on Supporting the Family and the Foster Care System].

Ustawa z dnia 11 lutego 2016 r. o pomocy państwa w wychowywaniu dzieci, Dz.U. z 2018 r. poz. 2134 i 2354 oraz z 2019 r. poz. 60, 303, 577 i 730. [Act of February 11, 2016 on State Child Support].

Ustawą z dnia 26 kwietnia 2019 r. o zmianie ustawy o pomocy państwa w wychowywaniu dzieci oraz niektórych innych ustaw, Dz.U. 2019, poz. 924. [The Act of April 26, 2019 amending the Act on State Child Support and Certain Other Acts].

\section{Literature}

Franielczyk, A. (2018). Program Rodzina 500+ w aspekcie wydatków publicznych [The 500+ programme and public spending]. Prace naukowe Uniwersytetu Ekonomicznego we Wrocławiu (528), 68-75.

Gajewicz, M. (2018). Dwa lata z programem Rodzina 500+ - ocena oraz uwarunkowania ekonomiczne programu [Two years with the Family 500+ programme - evaluation and economic conditions of the programme]. Prace naukowe Uniwersytetu Ekonomicznego we Wrocławiu (528), 76-87.

Gasz, M. (2018). Rola programu Rodzina 500+ w procesie redukcji zagrożenia ubóstwem i wykluczeniem społecznym w Polsce [The role of the Family $500+$ programme in the process of reducing the risk of poverty and social exclusion in Poland]. Prace naukowe Uniwersytetu Ekonomicznego we Wrocławiu (528), 88-101.

Graniszewski, L. (2018). Janus-face of the family 500 Plus Programme. Prace naukowe Uniwersytetu Ekonomicznego we Wrocławiu (528), 67$-74$.

Gromada, A. (2018). Czemu służy Program 500+. Analiza celów polityki publicznej i polityki partyjnej [What is the 500+ programme for? Analysis of the goals of public policy and party policy]. Ruch Prawniczy, Ekonomiczny i Socjologiczny (3) 2018, 231-244.

Hanusik, K., Łangowska-Szczęśniak, U. (2018). Wpływ Programu 500+ na poziom życia gospodarstw domowych wychowujących dzieci $\mathrm{i}$ jego samoocenę w Polsce w 2016 r. [Impact of the 500+ Programme on the living standards of households raising children and its selfevaluation in Poland in 2016.] Studia i Prace Wydziału Nauk Ekonomicznych i Zarządzania Uniwersytetu Szczecińskiego (51/3), 123-137.

Kotowska, I. (2014), Niska dzietność w Polsce w kontekście percepcji Polaków [Low fertility in Poland in the context of Polish people's perception]. Ministerstwo Rodziny i Polityki Społecznej i Centrum Rozwokju Ludkich Zasobów: Warszawa.

Krawczyk, M. (2019), Świadczenie 500" jako element polityki prorodzinnej i demograficznej państwa [Benefit 500" as an element of the profamily and demographic policy of the state]. Zeszyty Naukowe Uniwersytetu PrzyrodniczoHumanistycznego $w$ Siedlcach. Seria: Administracja i Zarządzanie 47 (120), 57-62.

Magda, I., Brzeziński, M., Chłoń-Domińczak, A., Kotowska, I.E., Myck, M., Najsztub, M., Tyrowicz, J., (2019) Rodzina 500 + - ocena programu i propozycje zmian [Family $500+"$ - evaluation of the programme and proposed changes], www.press-release 500 -pluspdfraport500 plusfinal-1, [accessed 20/12/2019]].

Michalak, J., Warzocha, Z., Liminowicz, P. (2018). Gospodarowanie budżetem domowym przez 
rodziny korzystające z programu Rodzina 500+ [Home budget management by families benefiting from the Family $500+$ programme]. Zeszyty Naukowe WSES w Ostrołęce 4 (31), 112-123.

Myck, M. Pakiet podatkowo-świadczeniowych rozwiązań rządu Zjednoczonej Prawicy, [The package of tax and benefit solutions of the government of the United Right]. www.cenea.org.pl, 12.04.2019.

Świecka, B. (2017). Świadczenie 500 plus jako transfer międzypokoleniowy [The 500 plus benefit as an intergenerational transfer. Przedsiębiorczość i Zarządzanie XVIII (9) (III), 59-70.

Węgrzyn, J. (2016). Mentalne budżetowanie gospodarstw domowych na przykładzie programu Rodzina 500+ [Household budgeting on the example of the Family $500+$ programme]. Przedsiębiorczośc i Zarządzanie XVII (8) (III), 267-278.

\section{Statistics}

CBOS, Program Rodzina 500 plus po trzech latach funkcjonowania, Komunikat z badań, nr 52/2019. [CBOS, Family 500 plus programme after three years of its functioning], Research report, No. 52/2019].

CBOS, Reakcje społeczne na rozwiązania tzw. Nowej Piątki PIS [Social reactions to PIS's five solutions], Research report 45/2019.

GUS, Praca a obowiązki rodzinne w II kwartale 2018 r. (na podstawie wstępnych wyników badania modułowego BAEL). [Work and family responsibilities in the second quarter of 2018 (based on the preliminary results of the BAEL module survey)].

GUS, Rocznik demograficzny 2019 [Demographic Yearbook 2019], Warszawa 2019.

\section{Other sources}

Gazeta Wyborcza, 500+ na pierwsze dziecko może zwiększyć aktywność zawodową kobiet, [dostęp: 31.12.2019 r.]. [Gazeta Wyborcza, $500+$ for the First Child may increase the Professional Activity of Women, online edition from: December 27, 2019 [accessed December 31, 2019]].

Ocena skutków regulacji zawartych w rządowym projekcie ustawy o zmianie ustawy o pomocy państwa $w$ wychowywaniu dzieci oraz niektórych innych ustaw [Assessment of the effects of regulations contained in the government bill amending the Act on State Aid in Raising Children and Certain Other Acts, Biuro Analiz Sejmowych, Chancellery of the Sejm, 23 April 2019].

Uzasadnienie do projektu ustawy o zmianie ustawy o pomocy państwa w wychowywaniu dzieci oraz niektórych innych ustaw [Justification for the Draft Act amending the act on State Aid for Child Support and certain other acts] no. 3387]. 